\title{
Triacyl Glycerols from Yeast-Catalyzed Batch and Fed-Batch Bioconversion of Hydrolyzed Lignocellulose from Cardoon Stalks
}

\author{
Domenico Aiello $^{1,2,+}{ }^{\mathbb{D}}$, Ciro Sannino ${ }^{1,+}{ }^{\text {, Tommaso Giannoni }}{ }^{2} \mathbb{D}$, Giacomo Fabbrizi ${ }^{2} \mathbb{D}$, Mattia Gelosia $^{2}$, \\ Andrea Nicolini ${ }^{2,3}{ }^{\mathbb{D}}$, Benedetta Turchetti ${ }^{1} \mathbb{D}$, Franco Cotana ${ }^{2,3}$ and Pietro Buzzini ${ }^{1,2, *(\mathbb{D})}$ \\ 1 Department of Agricultural, Food and Environmental Sciences, University of Perugia, 06121 Perugia, Italy; \\ domenico.aiello@unipg.it (D.A.); ciro.sannino@unipg.it (C.S.); benedetta.turchetti@unipg.it (B.T.) \\ 2 CIRIAF-Biomass Research Centre, University of Perugia, 06125 Perugia, Italy; giannoni@crbnet.it (T.G.); \\ giacomo.fabbrizi@studenti.unipg.it (G.F.); gelosia@crbnet.it (M.G.); andrea.nicolini@unipg.it (A.N.); \\ franco.cotana@unipg.it (F.C.) \\ 3 Department of Engineering, University of Perugia, 06125 Perugia, Italy \\ * Correspondence: pietro.buzzini@unipg.it \\ + These authors contributed equally to this work.
}

Citation: Aiello, D.; Sannino, C.; Giannoni, T.; Fabbrizi, G.; Gelosia, M.; Nicolini, A.; Turchetti, B.; Cotana, F.; Buzzini, P. Triacyl Glycerols from Yeast-Catalyzed Batch and Fed-Batch Bioconversion of Hydrolyzed Lignocellulose from Cardoon Stalks. Fermentation 2021, 7, 315. https:// doi.org/10.3390/fermentation7040315

Academic Editors: Alexander Rapoport, John E. Hallsworth, Justyna Ruchala and Tiffany D. Dallas

Received: 13 November 2021 Accepted: 14 December 2021 Published: 16 December 2021

Publisher's Note: MDPI stays neutral with regard to jurisdictional claims in published maps and institutional affiliations.

Copyright: (c) 2021 by the authors. Licensee MDPI, Basel, Switzerland. This article is an open access article distributed under the terms and conditions of the Creative Commons Attribution (CC BY) license (https:/ / creativecommons.org/licenses/by/ $4.0 /)$.
Abstract: The lipogenic ability of the yeast Solicoccozyma terricola DBVPG 5870 grown on hydrolyzed lignocellulose obtained from cardoon stalks was evaluated. Data on cell biomass, lipid production, and fatty acid profiles of triacylglycerols obtained in batch and fed-batch experiments were carried out at the laboratory scale in a 5L fermenter, and at two different temperatures (20 and $\left.25^{\circ} \mathrm{C}\right)$ were reported. The higher production of total intracellular lipids $(13.81 \mathrm{~g} / \mathrm{L})$ was found in the fed-batch experiments carried out at $20^{\circ} \mathrm{C}$. S. terricola exhibited the ability to produce high amounts of triacylglycerol (TAGs) with a characteristic fatty acids profile close to that of palm oil. The TAGs obtained from S. terricola grown on pre-treated lignocellulose could be proposed as a supplementary source of oleochemicals. Indeed, due to the rising prices of fossil fuels and because of the environmental-related issues linked to their employment, the use of TAGs produced by $S$. terricola grown on lignocellulose could represent a promising option as a supplementary oleochemical, especially for biodiesel production.

Keywords: Solicoccozyma terricola; biofuels; biochemicals; oleaginous yeast

\section{Introduction}

The increasing level of greenhouse gas emissions and the depletion of fossil fuel reserves are among the major concerns in the energy sector [1,2]. The excessive consumption of fossil fuels has elevated in the recent decades the average temperature of the Earth, thus causing severe impacts on terrestrial ecosystems and biological diversity [3]. In this regard, one of the objectives proposed by major world organizations for the mitigation of the effects of global warming is the research of alternative renewable energy sources. Biofuels have been considered promising substitutes of fossil fuels for mitigating the impact of greenhouse gas emissions [4,5]. They are classified based on their physical/chemical properties, nature, and biotechnological processes [6,7], and include bioethanol, biobutanol, biodiesel, and biogas [8].

The use of microorganisms for biofuels production via biotechnological conversion of biomass feedstock is regarded as an important step for reducing the dependence on fossil fuels [9]. Different fungal species can be used for the (whole or partial) production of biofuels due to their ability to produce high concentrations of oleochemicals or as biocatalyst for the transesterification process $[10,11]$. Among fungi, some yeasts exhibit advantages for lipid production over other oleaginous microorganisms, mainly due to their shorter duplication times, easier cultivation in large-scale fermenters, and rapid 
growth on different low-cost raw substrates [12]. The amount of intracellular lipid (almost exclusively constituted by triacylglycerols-TAGs) accumulated by yeasts is species- and even strain-dependent, with lipid content ranging from 20 to $70 \%$ of cell dry weight [13]. Due to the similarity of their fatty acids (FAs) profile with that of other organic oils, TAGs obtained from oleaginous yeasts may be regarded as a potential alternative to conventional vegetable oils (obtained from oil-seed crops) [14,15].

TAGs from oleaginous yeasts characterized by a prevalence of monounsaturated FAs can be considered good candidates for biodiesel production, but also for some food and cosmetic applications [14-22]. However, despite the above advantages, the global potential demand for TAGs from oleaginous yeasts is quite low due to their high production costs.

One of the possible ways for reducing the cost of biotechnological processes is the use of cheap substrates as $\mathrm{C}$ sources for supporting microbial growth and metabolism [23]. Thus, the use of lignocellulosic biomasses as raw $\mathrm{C}$ sources has been taken into consideration due to their wide availability in nature [24-26]. However, lignocellulosic feedstocks need mechanical, physical, and chemical pre-treatment to release free mono- and oligosaccharides supporting yeast growth and metabolism. Therefore, the lipogenic ability of oleaginous yeasts on pre-treated lignocellulosic biomasses has been widely studied [26-28].

Recently, some lignocellulosic feedstocks available in large quantities in the Mediterranean area were studied as C sources for TAGs accumulation by oleaginous yeasts in shaken-flask batch cultures. The yeast species Solicoccozyma terricola exhibited the highest lipogenic performances on pre-treated cardoon stalks [29]. Cardoon (Cynara cardunculus L.) is a non-food oilseed crop exhibiting growing in arid soils and needs low fertilization requirements. After oilseed harvest, about 12,000 tons/year of cardoon stalks are accumulated from Italian cultivations and their disposal is considered quite problematic [30-32].

The scaling-up of a given process from shaken-flask to fermenter may be regarded as a way to increase the production scale. In this sense, the goal of the scaling-up of a given biotechnological process is to replicate (and even to improve) the fermentation performances at a larger scale [33-37]. Along with everything, the use of fed-batch cultivation systems has been proposed as a valid implementation of conventional batch approaches for increasing the metabolic performances of a number of fermentation processes $[38,39]$, including those focused on lipid production [23,40-42].

The purpose of the present manuscript is to evaluate the lipogenic ability of the yeast $S$. terricola grown on hydrolyzed lignocelluloses obtained from cardoon stalks. Cell biomass, lipid production, and FAs profiles of TAGs obtained in batch and fed-batch experiments carried out at the laboratory scale in a $5 \mathrm{~L}$ fermenter at two different temperatures (20 and $25{ }^{\circ} \mathrm{C}$ ) are reported.

\section{Materials and Methods}

\subsection{Chemicals and Yeast Strain}

All chemicals were purchased from Sigma-Aldrich (St. Louis, MO, USA), while all media were from Oxoid (Roskilde, Denmark).

The strain Solicoccozyma terricola DBVPG 5870 used in this study was previously selected based on their superior lipogenic aptitude $[29,43]$ and was preserved at $-80{ }^{\circ} \mathrm{C}$ in the Industrial Yeast Collection DBVPG of the Department of Agricultural, Food and Environmental Sciences, University of Perugia, Italy. Salient information on the strain is reported on the DBVPG website (www.dbvpg.unipg.it, accessed on 13 November 2021). Working cultures were subcultured on YPD agar: $20 \mathrm{~g} / \mathrm{L}$ glucose, $10 \mathrm{~g} / \mathrm{L}$ yeast extract, $10 \mathrm{~g} / \mathrm{L}$ peptone, $20 \mathrm{~g} / \mathrm{L}$ agar, $\mathrm{pH}$ 6.0.

\subsection{Biomass Feedstocks and Steam Explosion Pre-Treatment}

The cardoon stalks (CS) were kindly provided by Matrica S.p.A (Porto Torres, Italy) in dried form. Composition of raw CS: cellulose (30.5\% \pm 0.5$)$, hemicellulose (17.2\% \pm 0.07$)$, acetyl groups deriving from hemicellulose deacetylation during biomass pretreatment $(5.0 \% \pm 0.12)$, pectin $(4.7 \% \pm 0.33)$, and lignin $(14.2 \% \pm 0.18)$. CS were treated as previously 
reported. Briefly, biomass feedstock was preliminary dried at $40{ }^{\circ} \mathrm{C}$ for 1 week and then subjected to size reduction ( $\min .1 \mathrm{~cm}$, max. $3 \mathrm{~cm}$ ) by a cutting mill. Steam-explosion (SE) of biomass was performed to deconstruct the lignocellulosic portion making it accessible to hydrolytic enzymes. SE of CS was conducted into a $11 \mathrm{~L}$ batch reactor (Biochemtex, Tortona, Italy) as reported by Cavalaglio et al. [44].

CS were firstly soaked in a $1.45 \% \mathrm{H}_{2} \mathrm{SO}_{4}$ solution $(w / w)$ overnight and, therefore, the solid portion was separated from the solution. The SE process was performed following the optimized conditions reported by Cavalaglio et al. [44]: briefly, CS biomass was subjected to SE pre-treatment at $166^{\circ} \mathrm{C}$ for $10 \mathrm{~min}$. Pre-treatment of lignocellulosic feedstocks via SE released two different fractions: (i) a water-insoluble substrate (WIS) containing a mixture of cellulose and lignin; and (ii) a pre-treatment liquor (Pt-L) containing hemicellulose, C5 carbohydrates, and some inhibitors, which need to be detoxified for allowing microbial growth and metabolism. The WIS was separated from Pt-L by a stainless-steel filter (cutoff $1 \mathrm{~mm}$ ), washed with water at $50^{\circ} \mathrm{C}$ for $30 \mathrm{~min}$ using a solid/liquid (S/L) ratio of $10 \%(w / w)$ [45] and then analyzed for their content of cellulose, hemicellulose and lignin following the National Renewable Energy Laboratory (NREL) analytical procedures [46]. Briefly, acid hydrolysis with $\mathrm{H}_{2} \mathrm{SO}_{4}$ of each sample was performed in triplicate to obtain $\mathrm{C} 5$ and $\mathrm{C} 6$ monomers from cellulose and hemicellulose. The concentration of both $\mathrm{C} 5$ and C6 monomers was detected by Dionex Ultimate 3000 HPLC (Thermo Scientific, Sunnyvale, CA, USA) equipped with a Biorad Aminex HPX-87H column (Biorad, CA, USA) thermoregulated at $50{ }^{\circ} \mathrm{C}$ and a RI detector (RefractoMax520, Thermo Scientific, Waltham, MA, USA), mobile phase $=0.01 \mathrm{~N} \mathrm{H}_{2} \mathrm{SO}_{4}$, flow $0.6 \mathrm{~mL} / \mathrm{min}$. The concentration of polymeric sugars was calculated using an anhydrous correction of 0.88 and 0.90 for C5 and C6 carbohydrates, respectively. The remaining acid-insoluble residue was used to calculate the acid-insoluble lignin after removing the ash content.

\subsection{Monosaccharides Production: Enzymatic Hydrolysis of WIS}

The WIS was selected for the subsequent phase of enzymatic hydrolysis to release mono- and oligosaccharides from cellulose, due to their higher contents of carbohydrates, as suggested by current literature [45,47-50]. Briefly, WIS of CS (S/L ratio of $5 \% w / w)$ was hydrolyzed for $72 \mathrm{~h}$ at $\mathrm{pH} 5$ and $50{ }^{\circ} \mathrm{C}$ in a $5 \mathrm{~L}$ Biostat ${ }^{\circledR}$ APlus-Sartorius stirred bioreactor (Sartorius, Goettingen, Germany). An enzyme cocktail solution (CTEC2, Novozyme, Denmark) with an activity of $150 \mathrm{FPU} / \mathrm{mL}$ and $5444 \mathrm{CBU} / \mathrm{mL}$ and a density of $1.3 \mathrm{~g} / \mathrm{mL}$ was used with a dosage of $0.3 \mathrm{~g} / \mathrm{g}$ of insoluble glucans (30\%). The bioreactor is equipped with an automatic monitoring and controlling system for rotation speed, $\mathrm{pH}$, aeration, temperature, and antifoam.

The solid-liquid separation following enzymatic hydrolysis was performed as follows: insoluble residual lignin fraction was separated from the carbohydrate-rich hydrolyzed liquid fraction by filtration (cut-off $0.45 \mu \mathrm{m}$ ) under pressure $\left(73 \mathrm{~g} / \mathrm{m}^{2}\right)$. The concentration of $C$ sources on hydrolyzed CS was determined by HPLC: glucose $=52.17 \pm 0.30 \mathrm{~g} / \mathrm{L}$, xylose $=3.27 \pm 0.27 \mathrm{~g} / \mathrm{L}$, cellobiose $=1.31 \pm 0.05 \mathrm{~g} / \mathrm{L}$, and acetic acid $=0.55 \pm 0.09 \mathrm{~g} / \mathrm{L}$.

To calculate the $\mathrm{C} / \mathrm{N}$ ratio, the total nitrogen content of hydrolyzed CS was determined by semi-micro Kjeldahl method as described in AOAC Official Methods SM [51]. After hydrolysis, the CS sample (hydrolyzed CS) were stored at $-20^{\circ} \mathrm{C}$ until use.

\subsection{Batch and Fed-Batch Experiments}

Batch and fed-batch cultures were carried out in triplicate at both 20 and $25{ }^{\circ} \mathrm{C}$ to check the influence of temperature on yeast lipogenic performances. A loopful of $48 \mathrm{~h}$ cells of $S$. terricola DBVPG 5870 was inoculated in $50 \mathrm{~mL}$ orbital shaken flasks (160 rpm) containing $10 \mathrm{~mL}$ of pre-culture medium (50\% of YPD broth and $50 \%$ of hydrolyzed CS). The $\mathrm{pH}$ of pre-culture media was adjusted to 5.5 with $\mathrm{NaOH} 1 \mathrm{M}$ and yeast extract was added to obtain a $\mathrm{C} / \mathrm{N}$ ratio of about 40 . After incubation at 20 or $25^{\circ} \mathrm{C}$ for $24 \mathrm{~h}$, the precultures were inoculated in $5 \mathrm{~L}$ bioreactors containing $1 \mathrm{~L}$ of hydrolyzed $\mathrm{CS}$ to reach 
a final concentration of $10^{7} \mathrm{UFC} / \mathrm{mL}$. $\mathrm{pH}$ was adjusted to 5.5 with $\mathrm{NaOH} 1 \mathrm{M}$ and yeast extract was added to obtain a C:N ratio of about 40:0 for batch fermentations.

For fed-batch fermentation yeast extract was added to reach a C:N ratio of 40:20, to promote cell growth rates and to increase the duration of the growth phase [52,53]. During batch and fed-batch experiments, the yeast growth was daily monitored spectrophotometrically while carbohydrate depletion was checked by HPLC. Batch fermentations were performed until the complete depletion of glucose. In fed-batch experiments, the substrate was maintained above $20 \mathrm{~g} / \mathrm{L}$ by feeding with hydrolyzed CS containing $120 \mathrm{~g} / \mathrm{L}$ of glucose, in agreement with a few studies [52-54] reporting this minimum value may be considered optimal for stimulating intracellular lipid accumulation in oleaginous yeasts. Aliquots of $10 \mathrm{~mL}$ were taken every $24 \mathrm{~h}$ to estimate glucose concentration, cell dry weight and total intracellular lipid content. A total of five cycles of substrates were done. After this point, the experiment was run until the complete depletion of glucose. In both batch and fed-batch experiments, $500 \mu \mathrm{L} / \mathrm{L}$ of silicon antifoam (Sigma-Aldrich, St. Louis, MO, USA) were added in the first days of fermentation in order to prevent foam formation.

\subsection{Extraction of Total Intracellular Lipids}

The extraction of total intracellular lipids was performed using the protocol previously reported [43]. Briefly, $10 \mathrm{~mL}$ of each culture were centrifuged $(5000 \times g$ for $10 \mathrm{~min})$ and repeatedly washed with distilled water. The cells were thus treated with $10 \mathrm{~mL}$ of $4 \mathrm{M}$ $\mathrm{HCl}$, incubated at $60^{\circ} \mathrm{C}$ for $2 \mathrm{~h}$ in a water bath to obtain acid-hydrolyzed cells, then mixed with $15 \mathrm{~mL}$ of a chloroform/methanol 2:1 $(\mathrm{v} / \mathrm{v})$ mixture and incubated at room temperature for $2 \mathrm{~h}$ in an orbital shaker at $160 \mathrm{rpm}$. After incubation, the samples were centrifuged (4000 rpm for $10 \mathrm{~min}$ ) to obtain the separation of the different phases. The organic phase containing the lipids was separated and put inside glass vials, which were fluxed to dryness in the dark by a gas nitrogen flow. Glasses were then instantly sealed with a rubber septum, weighed to determine the total of intracellular lipids, and stored at $-20^{\circ} \mathrm{C}$ until GC analysis. The weight of lipids extracted from yeast cells, the amount of yeast biomass produced after batch and fed-batch fermentations (both in shaken flasks or bioreactor), the content of glucose, xylose and cellobiose of the hydrolyzed biomass, and the duration of incubation required for obtaining the complete depletion of carbohydrates were used to calculate the following parameters: (i) the total intracellular lipid production $\left(\mathrm{P}_{\mathrm{L}}\right)$; (ii) \% of total intracellular lipid on cell biomass $\left(\mathrm{P}_{\mathrm{L}} / \mathrm{DW}\right)$; (iii) the lipid yield $\left(\mathrm{P}_{\mathrm{L}} / \mathrm{Glu}=\right.$ ratio between the total intracellular lipid production and the amount of total carbohydrates expressed as equivalent glucose used by yeasts for growth and metabolism).

\subsection{Determination of Fatty Acids (FAs) Profiles of Triacylglycerols (TAGs) by GC}

The determination of profiles of FAs in TAGs was performed with a GC Varian 3300 equipped with a FI-detector. Trans-esterification was carried out at room temperature in tubes for $1 \mathrm{~min}$ in $4 \mathrm{~mL}$ of $\mathrm{n}$-hexane and $160 \mu \mathrm{L}$ of sodium methoxide under vortex agitation. Work-up of the reaction was then conducted using $1.6 \mathrm{~mL}$ of a saturated solution of sodium chloride in $\mathrm{diH}_{2} \mathrm{O}$ to precipitate out salts and other reaction by-products. The samples were centrifuged ( $2000 \mathrm{rpm}$ for $5 \mathrm{~min}$ ) to obtain the separation of two different phases. The supernatant was separated and put in glass vials.

A TG-WaxMS capillary column (length $30 \mathrm{~m}$, internal diameter $0.25 \mathrm{~mm}$, film thickness of $0.25 \mu \mathrm{m}$ (Thermo-Fisher Scientific - Waltham, MA, USA) was used for the separation of the different FAs. The injector temperature was $250{ }^{\circ} \mathrm{C}$, the FI-detector temperature was $260^{\circ} \mathrm{C}$, and the oven temperature was programmed as follows: (i) an isotherm at $140{ }^{\circ} \mathrm{C}$ for $0 \mathrm{~min}$; (ii) a gradient $\left(6^{\circ} \mathrm{C} / \mathrm{min}\right)$ from 140 to $160^{\circ} \mathrm{C}$; (iii) a gradient $\left(8^{\circ} \mathrm{C} / \mathrm{min}\right)$ from 160 to $180^{\circ} \mathrm{C}$; (iv) a gradient $\left(4^{\circ} \mathrm{C} / \mathrm{min}\right)$ from 180 to $240^{\circ} \mathrm{C}$; and a final isotherm at $240{ }^{\circ} \mathrm{C}$ for $15 \mathrm{~min}$. Analytical high-purity gasses used helium as mobile phase, hydrogen as fuel, nitrogen as make-up gas, and air as oxidant. FAs profiles were identified by comparing their retention times with those of commercial standards of fatty acyl methyl esters (Fatty Acid Methyl Esters Standard Mixture, Sigma-Aldrich, Merck KGaA, Darmstadt, Germa- 
nia). Peak areas in the full chromatogram were used to determine their relative amounts. Watson's formula was used to calculate the degree of unsaturation (DU) of TAGs extracted from yeasts [55]:

$$
\mathrm{DU}=[\% \text { monoenes }+2(\% \text { dienes })+3(\% \text { trienes })] / 100
$$

\subsection{Statistical Analysis}

Batch and fed-batch fermentations were carried out in triplicate and the statistical analyses were performed using Student's $t$-test. Principal Component Analysis (PCA) was carried out on the FAs profiles using the $\mathrm{R}$ environment for statistical computing ( $\mathrm{R}$ core Team [56]). Data were not standardized prior to analysis and results relating to the main FA were displayed on correlation biplots.

In order to estimate potential physical parameters of biodiesel obtainable from TAGs produced by $S$. terricola in batch and fed-batch experiments performed at 20 and $25{ }^{\circ} \mathrm{C}$, FAs profiles were elaborated by empirical formulas, according to European Standards EN 14214: $\mathrm{CLSF}=$ chain length saturated factor; $\mathrm{OS}=$ oxidative stability; $\mathrm{CFPP}=$ cold filter plugging point; $\mathrm{KV}$ = kinematic viscosity; $\mathrm{D}=$ density; $\mathrm{SV}=$ saponification value; IV = iodine value; $\mathrm{CN}=$ cetane number; $\mathrm{HHV}=$ high heating value [57].

\section{Results}

\subsection{Lipogenic Aptitude in Batch and Fed-Batch Experiments}

No significant $(p>0.05)$ differences were found between the lipogenic aptitudes exhibited by $S$. terricola in batch experiments performed at 20 and $25^{\circ} \mathrm{C}$ (Table 1 ), while significant $(p<0.05)$ differences emerged between the fed-batch experiments carried out at the two different temperatures.

Table 1. Lipogenic aptitude of Solycoccozyma terricola in batch experiments performed at 20 and $25^{\circ} \mathrm{C}$. DW = cell dry weight; $\mathrm{P}_{\mathrm{L}}=$ total intracellular lipid production; $\mathrm{P}_{\mathrm{L}} / \mathrm{DW}=\%$ of total intracellular lipids on cell biomass; $\mathrm{P}_{\mathrm{L}} / \mathrm{Glu}=$ lipid yield. $\mathrm{P}_{\mathrm{L}} / \mathrm{d}$, daily lipid production. Different superscript letters show significant $(p<0.05)$ differences between experiments carried out at 20 and $25^{\circ} \mathrm{C}$.

\begin{tabular}{|c|c|c|c|c|c|}
\hline $\begin{array}{c}\mathrm{T} \\
\left({ }^{\circ} \mathrm{C}\right)\end{array}$ & $\begin{array}{c}\text { DW } \\
\text { (g/L of } \\
\text { Substrate) }\end{array}$ & $\begin{array}{c}P_{L} \\
\text { (g/L of Substrate) }\end{array}$ & $\begin{array}{c}P_{L} / D W \\
(\%)\end{array}$ & $\begin{array}{c}P_{L} / \text { Glu } \\
(\%)\end{array}$ & $\begin{array}{c}P_{L} / d \\
(g / L \text { of Substrate } \times \text { Day })\end{array}$ \\
\hline 20 & $17.58 \pm 1.03^{a}$ & $7.13 \pm 0.38^{a}$ & $40.7 \pm 4.38^{\mathrm{a}}$ & $14.24 \pm 1.83^{\mathrm{a}}$ & $1.43 \pm 0.08^{a}$ \\
\hline 25 & $15.96 \pm 0.76^{\mathrm{a}}$ & $6.68 \pm 0.48^{a}$ & $41.94 \pm 3.83^{\mathrm{a}}$ & $14.64 \pm 0.99^{a}$ & $1.34 \pm 0.10^{\mathrm{a}}$ \\
\hline
\end{tabular}

In this second case, a more rapid glucose depletion and the highest biomass accumulation was found at $20^{\circ} \mathrm{C}$ (Figures $1 \mathrm{~A}$ and $2 \mathrm{~A}$ ).

Likewise, $S$. terricola grown in fed-batch experiments exhibited a superior ability to accumulate significantly $(p<0.05)$ higher amounts of total intracellular lipids at $20{ }^{\circ} \mathrm{C}$ : $13.81 \mathrm{~g} / \mathrm{L}$ were observed at the end of fermentation (Figure 1B), while $9.69 \mathrm{~g} / \mathrm{L}$ of lipids were found at $25{ }^{\circ} \mathrm{C}$ (Figure 2B). This trend was the consequence of a higher biomass production (Figure 1A,B) combined with a higher percentage of total intracellular lipid on dry cells $\left(\mathrm{P}_{\mathrm{L}} / \mathrm{DW}\right)$ observed at $20^{\circ} \mathrm{C}$ (Figure $\left.2 \mathrm{~A}, \mathrm{~B}\right)$. Moreover, the fed-batch experiments carried out at $20^{\circ} \mathrm{C}$ showed a significantly $(p<0.05)$ higher lipid yield $\left(\mathrm{P}_{\mathrm{L}} / \mathrm{Glu}\right)$ than that observed at $25^{\circ} \mathrm{C}$ (Figures $1 \mathrm{~B}$ and $2 \mathrm{~B}$ ).

By comparing the different culture regiments, the higher lipogenic aptitude exhibited by fed-batch experiments is the consequence of the longer duration of the process (and therefore of a prolonged accumulation of cell biomass and intracellular lipids). Indeed, the percentage of total intracellular lipid on dry cells $\left(\mathrm{P}_{\mathrm{L}} / \mathrm{DW}\right)$ observed in fed-batch experiments carried out at $20^{\circ} \mathrm{C}$ (Figure $\left.1 \mathrm{~B}\right)$ were significantly $(p<0.05)$ higher than that observed in batch processes at both 20 and $25^{\circ} \mathrm{C}$ (Table 1). On the contrary, the average daily lipid production observed in fed-batch experiments $\left(\mathrm{P}_{\mathrm{L}} / \mathrm{d}=1.38 \pm 0.03\right.$, calculated on the basis of data reported in Figure $1 \mathrm{~B})$ was not significantly $(p<0.05)$ different than that obtained in 
batch fermentations (Table 1). Likewise, the lipid yield was not significantly $(p<0.05)$ affected by the different culture regiments used in the study (Table 1 and Figures 1 and 2).

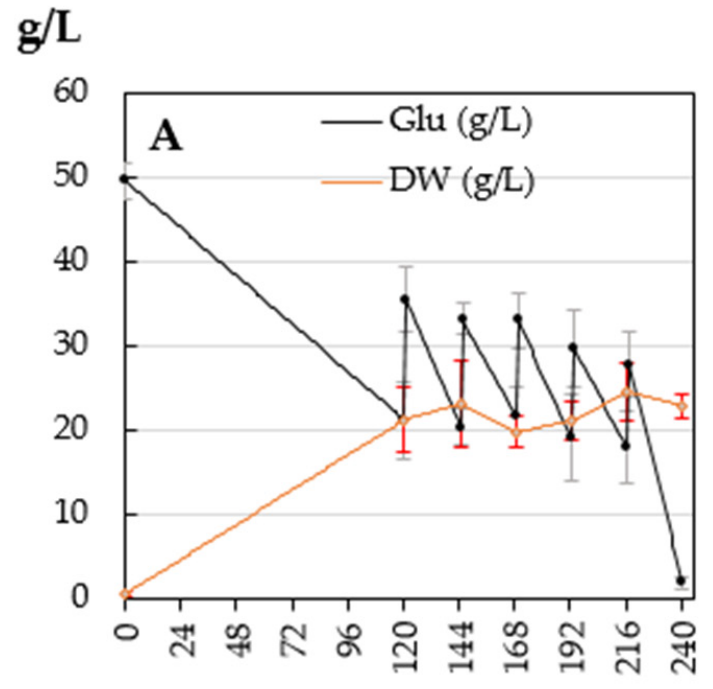

h

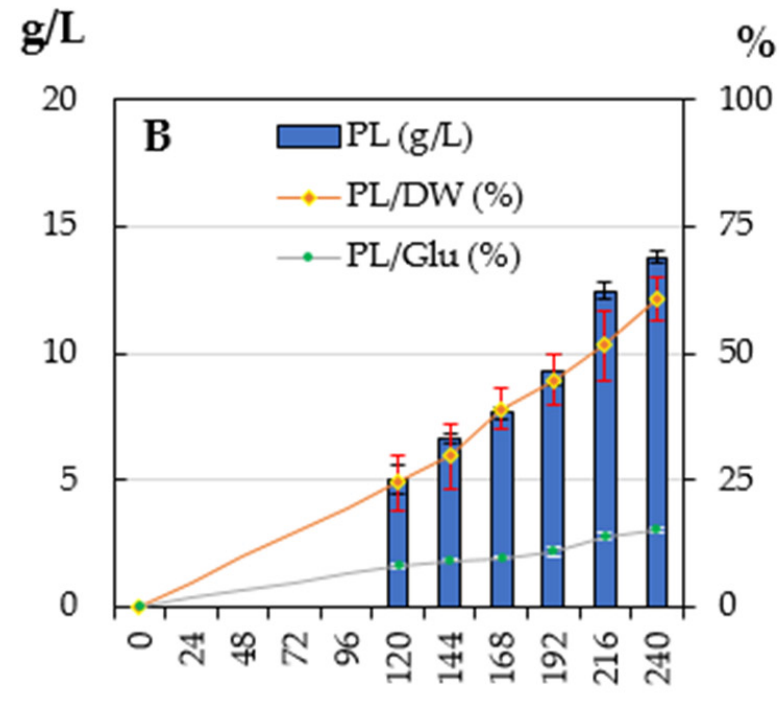

h

Figure 1. Fed-batch fermentation profile of Solicoccozyma terricola carried out at $20^{\circ} \mathrm{C}$. $(\mathbf{A})=$ time course of concentration of glucose $(\mathrm{Glu})$ and cell dry weight $(\mathrm{DW}) .(\mathrm{B})=$ time course of lipogenic ability; $\mathrm{P}_{\mathrm{L}}=$ total intracellular lipid production $(\mathrm{g} / \mathrm{L}$ of substrate); $\mathrm{P}_{\mathrm{L}} / \mathrm{DW}=\%$ of total intracellular lipids on cell $\mathrm{DW} ; \mathrm{P}_{\mathrm{L}} / \mathrm{Glu}=$ lipid yield.

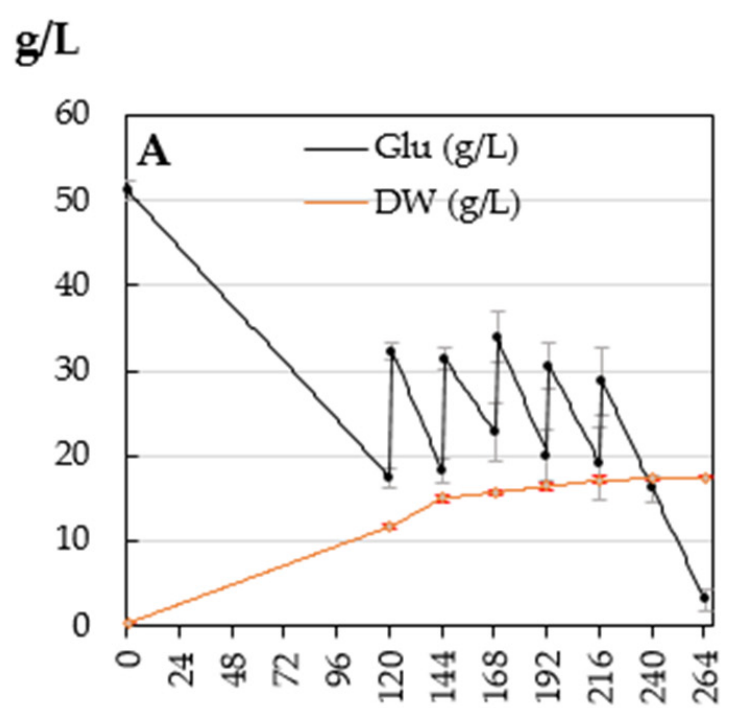

h

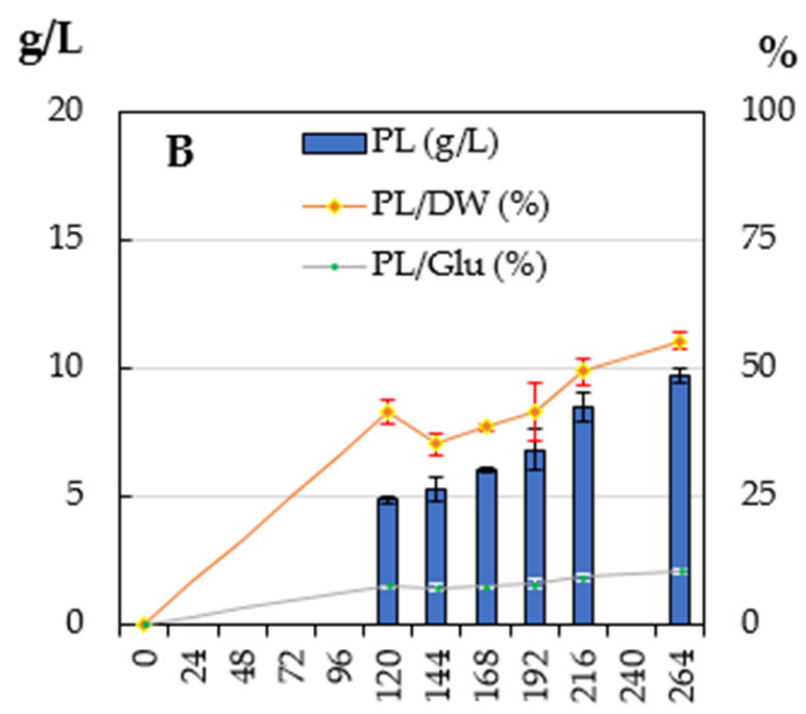

h

Figure 2. Fed-batch fermentation profile of Solicoccozyma terricola carried out at $25^{\circ} \mathrm{C}$. $(\mathrm{A})=$ time course of concentration of glucose $(\mathrm{Glu})$ and cell dry weight $(\mathrm{DW}) .(\mathbf{B})=$ time course of lipogenic ability: $\mathrm{P}_{\mathrm{L}}=$ total intracellular lipid production $(\mathrm{g} / \mathrm{L}$ of substrate); $\mathrm{P}_{\mathrm{L}} / \mathrm{DW}=\%$ of total intracellular lipids on cell $\mathrm{DW} ; \mathrm{P}_{\mathrm{L}} / \mathrm{Glu}=$ lipid yield.

\subsection{FAs Profiles of TAGs in Batch and Fed-Batch Experiments}

The FAs profiles of TAGs produced by $S$. terricola grown on CS-based substrate in batch and fed-batch experiments performed at 20 and $25^{\circ} \mathrm{C}$ are reported in Table 2. TAGs produced by $S$. terricola grown at $20^{\circ} \mathrm{C}$ in batch experiments exhibited a significantly $(p<0.05)$ higher percentage of unsaturated FAs (UFAs $=$ the sum of oleic acid and linoleic acid accounted for over $67 \%$ of the total FAs) than that found after growth at $25^{\circ} \mathrm{C}$. This trend was counterbalanced by a corresponding significant $(p<0.05)$ decrease of their 
corresponding saturated FAs (palmitic + stearic acids $=31.53 \%$ of the total) (Table 2). The same trend was observed in fed-batch experiments, where a higher abundance of UFA was found at $20{ }^{\circ} \mathrm{C}$ compared to that found after growth at $25^{\circ} \mathrm{C}$, coupled with a significant $(p<0.05)$ higher percentage of oleic acid and a parallel decrease of both palmitic and stearic acids (the sum of the two FAs accounted for over $37 \%$ of the total) (Table 2). Significant $(p<0.05)$ differences were found between 20 and $25^{\circ} \mathrm{C}$ in both batch and fed-batch experiments, especially in the terms of DU: overall, in both cases a higher DU was found at $20^{\circ} \mathrm{C}$ (163 and $134 \%$ of the value observed at the higher temperature, respectively) (Table 2 ).

Table 2. Fatty acids (FAs) profile of triacylglycerols (TAGs) produced by Solicoccozyma terricola in batch and fed-batch experiments, performed at 20 and $25^{\circ} \mathrm{C}$. Different superscript letters show significant $(p<0.05)$ differences between experiments carried out at 20 and $25^{\circ} \mathrm{C}$. SFA $=\%$ of saturated fatty acids; UFA $=\%$ of unsaturated fatty acids; DU, degree of unsaturation. C14:0 myristic acid (tetradecanoic acid), C16:0 palmitic acid (hexadecanoic acid), C16:1 palmitoleic acid [(9Z)hexadec-9-enoic acid), C18:0 stearic acid (octadecanoic acid), C18:1 oleic acid [(9E9Z)-octadec-9-enoic acid], C18:2 linoleic acid [(9Z,12Z)-9,12-octadecadienoic acid], C20:0 arachic acid (eicosanoic acid), C20:1 gondoic acid [(11Z)-11-eicosenoic acid], C22:0 behenic acid (docosanoic acid), C22:1 erucic acid [(13Z)-docos-13-enoic acid], C24:0 lignoceric acid (tetracosanoic acid). Different superscript letters indicate significant $(p<0.05)$ differences.

\begin{tabular}{|c|c|c|c|c|c|c|c|}
\hline & $\begin{array}{c}\mathrm{T} \\
\left({ }^{\circ} \mathrm{C}\right)\end{array}$ & $\begin{array}{c}\text { C14:0 } \\
(\%)\end{array}$ & $\begin{array}{c}\text { C16:0 } \\
(\%)\end{array}$ & $\begin{array}{c}\text { C16:1 } \\
(\%)\end{array}$ & $\begin{array}{c}\text { C18:0 } \\
(\%)\end{array}$ & $\begin{array}{c}\text { C18:1 } \\
\text { (\%) }\end{array}$ & $\begin{array}{c}\text { C18:2 } \\
(\%)\end{array}$ \\
\hline \multirow{2}{*}{ Batch } & 20 & $0.00^{\mathrm{a}}$ & $20.99 \pm 0.14^{\mathrm{a}}$ & $0.63 \pm 0.05^{a}$ & $10.54 \pm 0.22^{a}$ & $58.95 \pm 0.07^{a}$ & $8.06 \pm 0.15^{a}$ \\
\hline & 25 & $0.49 \pm 0.051^{b}$ & $33.13 \pm 0.71^{b}$ & $0.2 \pm 0.34^{\mathrm{a}}$ & $20.38 \pm 1.87^{b}$ & $44.06 \pm 0.9^{b}$ & $1.05 \pm 0.09^{b}$ \\
\hline \multirow{4}{*}{ Fed-batch } & 20 & $0.79 \pm 0.11^{a}$ & $29.53 \pm 0.93^{a}$ & $1.46 \pm 0.21^{\mathrm{a}}$ & $7.97 \pm 0.68^{a}$ & $56.19 \pm 0.26^{a}$ & $2.5 \pm 0.44^{\mathrm{a}}$ \\
\hline & 25 & $0.39 \pm 0.04^{b}$ & $36.67 \pm 1.31^{b}$ & $1.03 \pm 0.07^{\mathrm{a}}$ & $19.81 \pm 1.2^{b}$ & $36.75 \pm 0.52^{b}$ & $4.4 \pm 0.52^{b}$ \\
\hline & $T$ & C20:0 & C22:0 & C24:0 & SFA & UFA & DU \\
\hline & $\left({ }^{\circ} \mathrm{C}\right)$ & $(\%)$ & $(\%)$ & $(\%)$ & $(\%)$ & $(\%)$ & $(\%)$ \\
\hline \multirow{2}{*}{ Batch } & 20 & 0.00 & 0.00 & $0.83 \pm 0.04^{a}$ & 32.36 & 67.64 & 75.70 \\
\hline & 25 & 0.00 & 0.00 & $0.7 \pm 0.13^{a}$ & 54.69 & 45.31 & 46.36 \\
\hline \multirow[b]{2}{*}{ Fed-batch } & 20 & $0.35 \pm 0.26^{\mathrm{a}}$ & $0.11 \pm 0.01^{\mathrm{a}}$ & $0.6 \pm 0.12^{a}$ & 39.75 & 60.25 & 63.03 \\
\hline & 25 & $0.43 \pm 0.02^{\mathrm{a}}$ & $0.22 \pm 0.02^{b}$ & $0.2 \pm 0.01^{b}$ & 57.78 & 42.22 & 46.95 \\
\hline
\end{tabular}

PCA was used to compare the FAs profiles of TAGs produced by $S$. terricola in both batch and fed-batch experiments (performed at 20 and $25^{\circ} \mathrm{C}$ ) with the FAs profiles of some common vegetable oils (obtained from oil-seed crops) [58,59]. The sum of PC1 and PC2 was close to $100 \%$ of the total variance. Interestingly, PCA demonstrated that the FAs profiles of TAGs produced in both batch and fed-batch experiments were close to that of palm oil, mainly due to similar concentrations of both palmitic and stearic acids (Figure 3).

In order to estimate the potential physical parameters of biodiesel obtainable from TAGs produced by $S$. terricola in batch and fed-batch experiments performed at 20 and $25^{\circ} \mathrm{C}$, FAs profiles were elaborated by empirical formulas, according to European Standards EN 14214 [57]. Overall, with the sole exception of the oxidative stability (OS), the results were consistent with the references value for several parameters, namely kinematic viscosity (KV), density (D), saponification value (SV), iodine value (IV), and cetane number (CN) (Table 3).

In detail, $\mathrm{KV}$ and $\mathrm{D}$ were in the ranges between 3.5 to $5 \mathrm{~mm}^{2} / \mathrm{s}$ and 0.86 to $0.90 \mathrm{~g} / \mathrm{cm}^{3}$, respectively for all experiments. SV defines the amount of $\mathrm{KOH}$ in $\mathrm{mg}$ required to saponify one $g$ of oil under specific conditions [57]. This value generally has a minimum range of $0.5 \mathrm{~g}$, in these experiments, all trials reported over $190 \mathrm{mg}$ for $\mathrm{g}$ of oil. The parameter IV defined by the $\mathrm{mg}$ of $\mathrm{I}_{2}$ consumed by $100 \mathrm{~g}$ of substrates in a chemical reaction has a maximum value of $120 \mathrm{mg}$ : all results showed fewer values and the lowest was reported in the batch fermentation at $25^{\circ} \mathrm{C}$. Finally, all trials reported values slightly higher than 51 for CN (Table 3). 


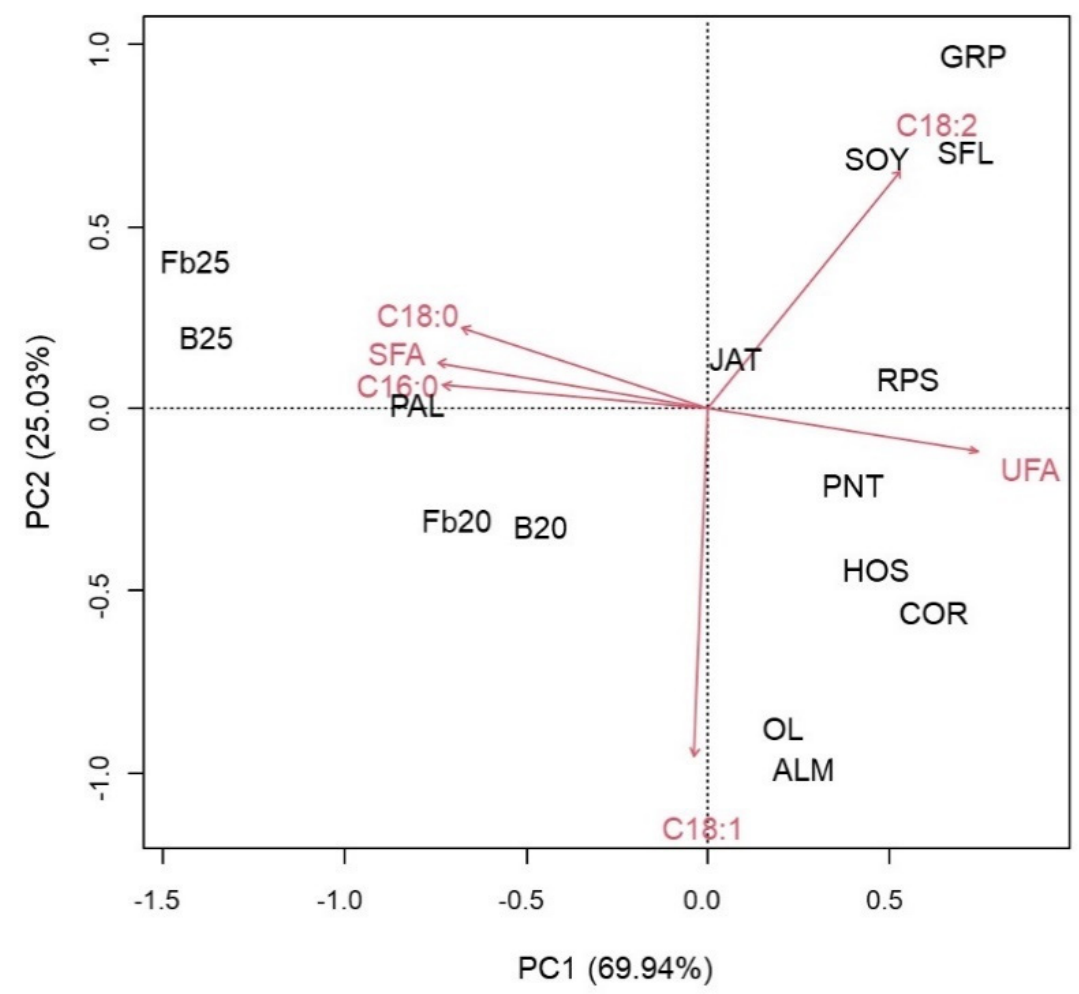

Figure 3. Comparison by PCA of fatty acid profiles of triacylglycerols (TAGs) produced by Solicoccozyma terricola in both batch and fed-batch experiments performed at 20 and $25{ }^{\circ} \mathrm{C}$ and those of some common vegetable oils. B20 and B25 = batch experiments at 20 and $25^{\circ} \mathrm{C}$, respectively; Fb20 and $\mathrm{Fb} 25$ = fed-batch experiments at 20 and $25^{\circ} \mathrm{C}$, respectively; PAL = red palm oil; $\mathrm{OL}=$ olive oil; $\mathrm{PNT}=$ peanut oil; $\mathrm{RPS}=$ rapeseed oil; $\mathrm{SOY}=$ soybean oil; $\mathrm{SFL}=$ sunflower oil; GRP $=$ grape oil; $\mathrm{HOS}$ $=$ High oleic sunflower; ALM $=$ almond oil; $\mathrm{COR}=$ Corn oil; $\mathrm{JAT}=$ Jatropha oil $[54,55] . \mathrm{SFA}=\%$ of saturated FA; UFA $=\%$ of unsaturated FA.

Table 3. Predictive estimation of the physical parameters of biodiesel obtainable using triacyl glycerols (TAGs) produced by Solicoccozyma terricola in batch and fed-batch experiments performed at 20 and $25{ }^{\circ} \mathrm{C}$. Data were calculated using results reported in Table 2. CLSF = chain length saturated factor; OS = oxidative stability; CFPP = cold filter plugging point; $\mathrm{KV}$ = kinematic viscosity; $\mathrm{D}=$ density; $\mathrm{SV}=$ saponification value; $\mathrm{IV}=$ iodine value; $\mathrm{CN}$ = cetane number; $\mathrm{HHV}=$ high heating value.

\begin{tabular}{|c|c|c|c|c|c|c|}
\hline & $\begin{array}{c}\mathrm{T} \\
\left({ }^{\circ} \mathrm{C}\right)\end{array}$ & $\begin{array}{l}\text { CLSF } \\
(\%)\end{array}$ & $\begin{array}{l}\text { OS } \\
\text { (h) }\end{array}$ & $\begin{array}{l}\text { CFPP } \\
\left({ }^{\circ} \mathrm{C}\right)\end{array}$ & $\begin{array}{c}\mathrm{KV} \\
\left(\mathrm{mm}^{2} / \mathrm{s}\right)\end{array}$ & $\underset{\left(\mathrm{g} / \mathrm{cm}^{3}\right)}{D}$ \\
\hline Reference values/ranges & & Not specified & $\geq 6 \mathrm{~h}$ & Variable * & $3.5-5$ & $0.86-0.90$ \\
\hline \multirow{2}{*}{ Batch experiments } & 20 & 10.91 & 4.86 & 4.38 & 4.63 & 0.87 \\
\hline & 25 & 18.41 & 5.99 & 17.55 & 4.74 & 0.86 \\
\hline \multirow{3}{*}{ Fed-batch experiments } & 20 & 12.75 & 5.35 & 7.61 & 4.56 & 0.87 \\
\hline & 25 & 19.28 & 5.97 & 19.08 & 4.73 & 0.86 \\
\hline & $\begin{array}{c}\mathrm{T} \\
\left({ }^{\circ} \mathrm{C}\right)\end{array}$ & \multicolumn{2}{|c|}{$\begin{array}{c}\mathrm{SV} \\
\text { (mg KOH/g of oil) }\end{array}$} & $\begin{array}{c}\text { IV } \\
\left(\mathrm{mg} \mathrm{I}_{2} / 100 \mathrm{~g}\right)\end{array}$ & $\mathrm{CN}$ & $\begin{array}{c}\text { HHV } \\
(\mathrm{MJ} / \mathrm{Kg})\end{array}$ \\
\hline Reference values/ranges & & \multicolumn{2}{|c|}{$\geq 0.50$} & $\leq 120$ & $\geq 51$ & Not specified \\
\hline \multirow{2}{*}{ Batch experiments } & 20 & \multicolumn{2}{|c|}{192.42} & 65.00 & 58.09 & 39.87 \\
\hline & 25 & \multicolumn{2}{|c|}{194.61} & 39.74 & 64.21 & 39.86 \\
\hline \multirow{2}{*}{ Fed-batch experiments } & 20 & \multirow{2}{*}{\multicolumn{2}{|c|}{194.91}} & 54.14 & 60.50 & 39.86 \\
\hline & 25 & & & 40.34 & 63.87 & 39.92 \\
\hline
\end{tabular}

* Depending on geography and period of year. 


\section{Discussion}

In light of the results herein reported, the possibility of using lipids produced by oleaginous yeasts from pre-treated lignocelluloses obtained from cardoon stalks as sustainable and cheap extra-source of oils (exhibiting a FAs profile comparable with that of palm oil) could be regarded as a realistic chance, also in view of the rising global request of oleochemicals and biofuels obtained from biotechnological processes $[60,61]$.

Previous studies investigated the lipogenic ability of $S$. terricola grown in batch fermentations on both different pure sugars (glucose, glycerol, xylose, galactose, sucrose, maltose, and cellobiose) and on different lignocellulosic biomasses (cardoon stalks, stranded driftwood and olive tree pruning residues): a superior lipogenic ability was found when S. terricola was grown on lignocellulosic biomasses, especially in media containing hydrolyzed lignocelluloses obtained from cardoon stalks $[29,43]$.

S. terricola grown in fed-batch experiments exhibited a higher lipogenic aptitude at $20{ }^{\circ} \mathrm{C}$. Despite batch culture being the most studied approach to select novel lipidoverproducing yeasts [62], the use of fed-batch cultures has been proposed as a possible upgrade for improving metabolic performances of oleaginous yeasts, mainly in the terms of production of cell biomass and intracellular lipids [63,64]. Fed-batch fermentations carried out at $20{ }^{\circ} \mathrm{C}$ exhibited the higher values of $\%$ of total intracellular lipid on cell biomass $\left(\mathrm{P}_{\mathrm{L}} / \mathrm{DW}\right)$, despite the lipid yield $\left(\mathrm{P}_{\mathrm{L}} / \mathrm{Glu}\right)$ being quite far from the maximum theoretical value [65], as opposed to the results reported by Tasselli et al. [29], who found that this species was able to reach a lipid yield close to the maximum theoretical value when grown on CS in shaken flasks at $20^{\circ} \mathrm{C}$. Overall, S. terricola exhibited the higher ability to accumulate high amounts of total intracellular lipids when grown in fed-batch experiments carried out at $20^{\circ} \mathrm{C}$ as a consequence of its superior ability to produce yeast biomass and to accumulate lipids at the cytoplasmic level. The other relevant parameters (i.e., yield and daily productivity) was not significantly $(p<0.05)$ affected by the different culture regiments.

Overall, the main parameter affecting the lipogenic aptitude of $S$. terricola was the temperature. The yeast species Metschnikowia pulcherrima showed a temperature-dependent trend within a range of temperature from 15 to $30{ }^{\circ} \mathrm{C}$, especially for biomass and lipid yields, and FAs profile. A remarkable decrease of DU and of short chain FAs (C14:0, C16:0, and C16:1), and a parallel increase of oleic acid suggested that at low temperatures the activity of desaturases could be stimulated at the expenses of that of elongases [66]. This temperature-related trend was also observed in Saccharomyces cerevisiae and was correlated with genome regulation, indicating that the transcription of genes encoding for desaturase is apparently activated at low temperatures, probably because unsaturated FAs has been understood to express an important role in maintaining the cell membrane fluidity [67]. Likewise, D12-fatty acid desaturases from Yarrowia lipolytica were expressed to a higher extent at low temperature $\left(12{ }^{\circ} \mathrm{C}\right)$, thus increasing DU, although no higher accumulation of intracellular lipids were found [68].

Principal Component Analysis (PCA) revealed that the FAs profile of TAGs produced by $S$. terricola in both batch and fed-batch fermentations at 20 and $25^{\circ} \mathrm{C}$ was similar to that of palm oil, as reported by Ramos et al. [59]. Palm oil was in recent decades the most widely used terrestrial oil crops and its market is projected to continue expanding at a rate of approximately $2 \%$ per year $[69,70]$. Palm oil is widely used worldwide for its lower cost and for its almost perfect equilibrium (50:50) between the concentration of both saturated and unsaturated FAs [71]. The high demand for palm oil is stimulating debates on the environmental consequences determined by the conversion of forest land and agricultural land to oil palm cultivations, which can generate environmental implications, such as greenhouse gas emissions from changes in soil carbon stocks and biomass, forest fires, air pollutant emissions, losses of biodiversity, and losses of animals, plants, and species in forest ecosystems [72-76]. Therefore, TAGs obtained from oleaginous yeasts grown on pretreated lignocellulosic biomass could be proposed as a supplementary source of oleochemicals, which could be regarded as an alternative to palm oil request $[52,77,78]$. On 
the other hand, PCA suggested that the FAs profile of TAGs produced by S. terricola in both batch and fed-batch fermentations carried out at 20 and $25^{\circ} \mathrm{C}$ were quite far from those reported for other vegetable oils rich in unsaturated FFAs. Considering that the double bonds of FFAs are used as possible polymerization points [79], the TAGs synthesized by S. terricola in this study were not apparently suitable to be proposed as building blocks for obtaining microbial biopolymers. However, since in both culture regiments a general increase of the unsaturation degree (DU) was observed from 25 to $20^{\circ} \mathrm{C}$, as a consequence of a general acclimatory response of cold-adapted yeast to lower temperatures [80], we could postulate that the use of lower incubation temperatures (e.g., $10-15^{\circ} \mathrm{C}$ or below) could significantly increase the DU of the FFAs, thus allowing the use of the TAGs obtained by $S$. terricola for the production of biopolymers.

Due to the rising prices of fossil fuels and because of the environmental-related issues linked to their employment, the use of lipids produced by oleaginous microorganisms grown on lignocelluloses could represent a promising option, also in view of reducing any potential competition with food resources [81]. In this framework, oils exhibiting a high $\%$ of unsaturated FAs (e.g., oleic acid) could be considered good candidates to be used as supplementary oleochemicals, especially for biodiesel production [82].

The increase of energy demand coping with the utilization of fossil resources has engendered a number of serious environmental impacts. Therefore, a progressively stringent worldwide legislation was promulgated for the purpose of reducing greenhouse gas emissions and stimulating significant research efforts on the development of alternative fuels [83]. In this context, the lipid produced by S. terricola at $25{ }^{\circ} \mathrm{C}$ should be an alternative for biodiesel production [59]. The predicted biodiesel parameters calculated following currently used formulas [57] were in the range suggested by the European Standards EN 14214, with the sole exception of a lower value of oxidative stability OS (lower than the reference value in EN14214), similarly to other biodiesel derived from vegetable oils, due to the long chain fatty acid alkyl esters, which contains unsaturated portions that are susceptible to oxidation [83].

\section{Conclusions}

Recent studies have compared biodiesel production via biotechnological approaches in the marketplace with traditional production processes. The cost of biodiesel obtained from microbial oils is actually estimated at $12.8 \mathrm{USD} / \mathrm{kg}$, almost fifteen times higher than the current market price of conventional biodiesel obtained from oilseed crops (about 0.9 USD $/ \mathrm{kg}$ ) [84]. The use of cheaper C sources (e.g., agro-industrial wastes and non-food crops) allowing the lipid accumulation by oleaginous yeasts should reduce the production costs around 50\% [29]. Of course, any decrease in costs is also a function of production volumes: Parsons et al. [69] determined a minimum estimated selling price of about $14 \mathrm{USD} / \mathrm{kg}$ using cheap carbon sources (sucrose and wheat straw) and showed how this value was reduced by around $45 \%$ on scaling of 10,000 ton/y [85]. Therefore, if the use of cheaper C sources (e.g., cardoon stalks) may be regarded as an easy way to reduce the production costs of biodiesel obtained from microbial oils, the optimization of the industrial process is a good strategy to be followed. In this context, the strain S. terricola DBVPG 5870 used in this study (previously selected based on their superior lipogenic aptitude) exhibited the ability of producing high amounts of TAGs from lignocelluloses obtained from agro-industrial wastes (i.e., crops cardoon stalks). Fed-batch fermentations showed better performances than batch experiments demonstrating their aptitude to be exploited for possible future application on ever-increasing production scales. Interestingly, TAGs produced by S. terricola DBVPG 5870 exhibited an FAs profile similar to that of palm oil and compatible with a possible conversion in biodiesel. 
Author Contributions: D.A. and C.S. performed the biotechnological experiments and wrote the manuscript; T.G., G.F. and M.G. performed the collection and pre-treatment of cardoon stalks; A.N. and F.C. reviewed the draft and coordinated the fund acquisition; B.T. and P.B. designed the experiments, wrote and reviewed the manuscript. All authors have read and agreed to the published version of the manuscript.

Funding: D.A.'s fellowship was supported by the Italian Ministry for Education and Scientific Research (MIUR) through the project: "Biofeedstock-sviluppo di piattaforme tecnologiche integrate per la valorizzazione di biomasse residuali" (Project No. PON_BIOFEEDSTOCK_ARS01_00985).

Institutional Review Board Statement: Not applicable.

Informed Consent Statement: Not applicable.

Data Availability Statement: Not applicable.

Acknowledgments: The authors thank A. Bertini for his valuable help in some laboratory steps.

Conflicts of Interest: The authors declare no conflict of interest.

\section{References}

1. Neukirchen, F.; Ries, G. The World of Mineral Deposits: A Beginner's Guide to Economic Geology; Springer International Publishing: Cham, Switzerland, 2020; ISBN 978-3-030-34345-3.

2. Peters, G.P.; Andrew, R.M.; Canadell, J.G.; Friedlingstein, P.; Jackson, R.B.; Korsbakken, J.I.; Le Quéré, C.; Peregon, A. Carbon Dioxide Emissions Continue to Grow amidst Slowly Emerging Climate Policies. Nat. Clim. Chang. 2020, 10, 3-6. [CrossRef]

3. Umar, M.; Ji, X.; Kirikkaleli, D.; Xu, Q. COP21 Roadmap: Do Innovation, Financial Development, and Transportation Infrastructure Matter for Environmental Sustainability in China? J. Environ. Manag. 2020, 271, 111026. [CrossRef]

4. Adeniyi, O.M.; Azimov, U.; Burluka, A. Algae Biofuel: Current Status and Future Applications. Renew. Sustain. Energy Rev. 2018, 90, 316-335. [CrossRef]

5. Zeppini, P.; van den Bergh, J.C.J.M. Global Competition Dynamics of Fossil Fuels and Renewable Energy under Climate Policies and Peak Oil: A Behavioural Model. Energy Policy 2020, 136, 110907. [CrossRef]

6. Ajanovic, A. Biofuels versus Food Production: Does Biofuels Production Increase Food Prices? Energy 2011, 36, 2070-2076. [CrossRef]

7. Tsita, K.G.; Kiartzis, S.J.; Ntavos, N.K.; Pilavachi, P.A. Next Generation Biofuels Derived from Thermal and Chemical Conversion of the Greek Transport Sector. Therm. Sci. Eng. Prog. 2020, 17, 100387. [CrossRef]

8. Abraham, A.; Mathew, A.K.; Park, H.; Choi, O.; Sindhu, R.; Parameswaran, B.; Pandey, A.; Park, J.H.; Sang, B.I. Pretreatment Strategies for Enhanced Biogas Production from Lignocellulosic Biomass. Bioresour. Technol. 2020, 301, 122725. [CrossRef]

9. Raven, S.; Francis, A.; Srivastava, C.; Kezo, S.; Tiwari, A.; Yadav, A.N.; Singh, S.; Mishra, S.; Gupta, A. Fungal Biofuels: Innovative Approaches. In Recent Advancement in White Biotechnology through Fungi: Volume 2: Perspective for Value-Added Products and Environments; Fungal Biology; Springer International Publishing: Cham, Switzerland, 2019; pp. 385-405, ISBN 978-3-030-14846-1.

10. Salehi Jouzani, G.; Taherzadeh, M.J. Advances in Consolidated Bioprocessing Systems for Bioethanol and Butanol Production from Biomass: A Comprehensive Review. Biofuel Res. J. 2015, 2, 152-195. [CrossRef]

11. Salehi Jouzani, G.; Tabatabaei, M.; Aghbashlo, M. Fungi in Fuel Biotechnology; Fungal Biology; Springer International Publishing: Cham, Switzerland, 2020; ISBN 978-3-030-44487-7.

12. Adrio, J.L. Oleaginous Yeasts: Promising Platforms for the Production of Oleochemicals and Biofuels. Biotechnol. Bioeng. 2017, 114, 1915-1920. [CrossRef] [PubMed]

13. Cohen, Z.; Ratledge, C. Single Cell Oils for the 21st Century. In Single Cell Oils; AOCS Publishing: Urbana, IL, USA, 2005; ISBN 978-1-00-304010-1.

14. Kot, A.M.; Błażejak, S.; Kurcz, A.; Gientka, I.; Kieliszek, M. Rhodotorula Glutinis-Potential Source of Lipids, Carotenoids, and Enzymes for Use in Industries. Appl. Microbiol. Biotechnol. 2016, 100, 6103-6117. [CrossRef] [PubMed]

15. Wang, W.; Wei, H.; Knoshaug, E.; Van Wychen, S.; Xu, Q.; Himmel, M.E.; Zhang, M. Fatty Alcohol Production in Lipomyces Starkeyi and Yarrowia Lipolytica. Biotechnol. Biofuels 2016, 9, 227. [CrossRef] [PubMed]

16. Lopez-Huertas, E. Health Effects of Oleic Acid and Long Chain Omega-3 Fatty Acids (EPA and DHA) Enriched Milks. A Review of Intervention Studies. Pharmacol. Res. 2010, 61, 200-207. [CrossRef] [PubMed]

17. Ageitos, J.M.; Vallejo, J.A.; Veiga-Crespo, P.; Villa, T.G. Oily Yeasts as Oleaginous Cell Factories. Appl. Microbiol. Biotechnol. 2011, 90, 1219-1227. [CrossRef]

18. Mennella, I.; Savarese, M.; Ferracane, R.; Sacchi, R.; Vitaglione, P. Oleic Acid Content of a Meal Promotes Oleoylethanolamide Response and Reduces Subsequent Energy Intake in Humans. Food Funct. 2015, 6, 204-210. [CrossRef] [PubMed]

19. Elkacmi, R.; Kamil, N.; Bennajah, M.; Kitane, S. Extraction of Oleic Acid from Moroccan Olive Mill Wastewater. BioMed Res. Int. 2016, 2016, e1397852. [CrossRef]

20. Agarwal, S. Comparative Fatty Acid and Trace Elemental Analysis Identified the Best Raw Material of Jojoba (Simmondsia chinensis) for Commercial Applications. Ann. Agric. Sci. 2018, 63, 37-45. [CrossRef] 
21. Alismaeel, Z.T.; Abbas, A.S.; Albayati, T.M.; Doyle, A.M. Biodiesel from Batch and Continuous Oleic Acid Esterification Using Zeolite Catalysts. Fuel 2018, 234, 170-176. [CrossRef]

22. Cannilla, C.; Bonura, G.; Costa, F.; Frusteri, F. Biofuels Production by Esterification of Oleic Acid with Ethanol Using a Membrane Assisted Reactor in Vapour Permeation Configuration. Appl. Catal. A Gen. 2018, 566, 121-129. [CrossRef]

23. Das, M.; Yash, K.; Khan, M.A. Oleaginous Yeast as Potential Lipid Producing Organism: A Review. Plant Arch. 2021, 21, 1830-1833. [CrossRef]

24. Papanikolaou, S.; Aggelis, G. Lipids of Oleaginous Yeasts. Part II: Technology and Potential Applications. Eur. J. Lipid Sci. Technol. 2011, 113, 1052-1073. [CrossRef]

25. Sitepu, I.R.; Garay, L.A.; Sestric, R.; Levin, D.; Block, D.E.; German, J.B.; Boundy-Mills, K.L. Oleaginous Yeasts for Biodiesel: Current and Future Trends in Biology and Production. Biotechnol. Adv. 2014, 32, 1336-1360. [CrossRef] [PubMed]

26. Karlsson, H.; Ahlgren, S.; Sandgren, M.; Passoth, V.; Wallberg, O.; Hansson, P.-A. A Systems Analysis of Biodiesel Production from Wheat Straw Using Oleaginous Yeast: Process Design, Mass and Energy Balances. Biotechnol. Biofuels 2016, 9, 229. [CrossRef]

27. Yu, X.; Zheng, Y.; Dorgan, K.M.; Chen, S. Oil Production by Oleaginous Yeasts Using the Hydrolysate from Pretreatment of Wheat Straw with Dilute Sulfuric Acid. Bioresour. Technol. 2011, 102, 6134-6140. [CrossRef]

28. Bonturi, N.; Crucello, A.; Viana, A.J.C.; Miranda, E.A. Microbial Oil Production in Sugarcane Bagasse Hemicellulosic Hydrolysate without Nutrient Supplementation by a Rhodosporidium toruloides Adapted Strain. Process Biochem. 2017, 57, 16-25. [CrossRef]

29. Tasselli, G.; Filippucci, S.; Borsella, E.; D’Antonio, S.; Gelosia, M.; Cavalaglio, G.; Turchetti, B.; Sannino, C.; Onofri, A.; Mastrolitti, S.; et al. Yeast Lipids from Cardoon Stalks, Stranded Driftwood and Olive Tree Pruning Residues as Possible Extra Sources of Oils for Producing Biofuels and Biochemicals. Biotechnol. Biofuels 2018, 11, 147. [CrossRef]

30. Angelini, L.G.; Ceccarini, L.; Nassi o Di Nasso, N.; Bonari, E. Long-Term Evaluation of Biomass Production and Quality of Two Cardoon (Cynara cardunculus L.) Cultivars for Energy Use. Biomass Bioenergy 2009, 33, 810-816. [CrossRef]

31. Ciancolini, A.; Alignan, M.; Pagnotta, M.A.; Vilarem, G.; Crinò, P. Selection of Italian Cardoon Genotypes as Industrial Crop for Biomass and Polyphenol Production. Ind. Crop. Prod. 2013, 51, 145-151. [CrossRef]

32. Ierna, A.; Mauromicale, G. Cynara cardunculus L. Genotypes as a Crop for Energy Purposes in a Mediterranean Environment. Biomass Bioenergy 2010, 34, 754-760. [CrossRef]

33. Hsu, Y.-L.; Wu, W.-T. A Novel Approach for Scaling-up a Fermentation System. Biochem. Eng. J. 2002, 11, 123-130. [CrossRef]

34. Formenti, L.R.; Nørregaard, A.; Bolic, A.; Hernandez, D.Q.; Hagemann, T.; Heins, A.-L.; Larsson, H.; Mears, L.; Mauricio-Iglesias, M.; Krühne, U.; et al. Challenges in Industrial Fermentation Technology Research. Biotechnol. J. 2014, 9, 727-738. [CrossRef] [PubMed]

35. Hewitt, C.J.; Nienow, A.W. The Scale-up of Microbial Batch and Fed-Batch Fermentation Processes. Adv. Appl. Microbiol. 2007, 62, 105-135. [CrossRef] [PubMed]

36. Yang, X. Scale-Up of Microbial Fermentation Process. In Manual of Industrial Microbiology and Biotechnology; John Wiley \& Sons, Ltd.: Hoboken, NJ, USA, 2010; pp. 669-675, ISBN 978-1-68367-128-2.

37. Schmidt, F.R. Optimization and Scale up of Industrial Fermentation Processes. Appl. Microbiol. Biotechnol. 2005, 68, 425-435. [CrossRef] [PubMed]

38. Fu, X.; Wang, Y.; Wang, J.; Garza, E.; Manow, R.; Zhou, S. Semi-Industrial Scale (30 M3) Fed-Batch Fermentation for the Production of D-Lactate by Escherichia coli Strain HBUT-D15. J. Ind. Microbiol. Biotechnol. 2017, 44, 221-228. [CrossRef]

39. Ye, H.; He, Y.; Xie, Y.; Sen, B.; Wang, G. Fed-Batch Fermentation of Mixed Carbon Source Significantly Enhances the Production of Docosahexaenoic Acid in Thraustochytriidae sp. PKU\#Mn16 by Differentially Regulating Fatty Acids Biosynthetic Pathways. Bioresour. Technol. 2020, 297, 122402. [CrossRef]

40. Chen, J.; Zhang, X.; Yan, S.; Tyagi, R.D.; Drogui, P. Lipid Production from Fed-Batch Fermentation of Crude Glycerol Directed by the Kinetic Study of Batch Fermentations. Fuel 2017, 209, 1-9. [CrossRef]

41. Fei, Q.; Wewetzer, S.J.; Kurosawa, K.; Rha, C.; Sinskey, A.J. High-Cell-Density Cultivation of an Engineered Rhodococcus opacus Strain for Lipid Production via Co-Fermentation of Glucose and Xylose. Process Biochem. 2015, 50, 500-506. [CrossRef]

42. Ji, F.; Zhou, Y.; Pang, A.; Ning, L.; Rodgers, K.; Liu, Y.; Dong, R. Fed-Batch Cultivation of Desmodesmus sp. in Anaerobic Digestion Wastewater for Improved Nutrient Removal and Biodiesel Production. Bioresour. Technol. 2015, 184, 116-122. [CrossRef]

43. Filippucci, S.; Tasselli, G.; Scardua, A.; Di Mauro, S.; Cramarossa, M.R.; Perini, D.; Turchetti, B.; Onofri, A.; Forti, L.; Buzzini, P. Study of Holtermanniella wattica, Leucosporidium creatinivorum, Naganishia adeliensis, Solicoccozyma aeria, and Solicoccozyma terricola for Their Lipogenic Aptitude from Different Carbon Sources. Biotechnol. Biofuels 2016, 9, 259. [CrossRef]

44. Cavalaglio, G.; Gelosia, M.; Giannoni, T.; Barros Lovate Temporim, R.; Nicolini, A.; Cotana, F.; Bertini, A. Acid-catalyzed steam explosion for high enzymatic saccharification and low inhibitor release from lignocellulosic cardoon stalks. Biochem. Eng. J. 2021, 174, 108121. [CrossRef]

45. Sluiter, J.B.; Ruiz, R.O.; Scarlata, C.J.; Sluiter, A.D.; Templeton, D.W. Compositional Analysis of Lignocellulosic Feedstocks. 1. Review and Description of Methods. J. Agric. Food Chem. 2010, 58, 9043-9053. [CrossRef]

46. Sluiter, J.; Sluiter, A. Summative Mass Closure; NREL/TP-510-48087; NREL: Golden, CO, USA, 2010; pp. 1-10.

47. Cavalaglio, G.; Gelosia, M.; D’Antonio, S.; Nicolini, A.; Pisello, A.L.; Barbanera, M.; Cotana, F. Lignocellulosic Ethanol Production from the Recovery of Stranded Driftwood Residues. Energies 2016, 9, 634. [CrossRef]

48. Cara, C.; Ruiz, E.; Oliva, J.M.; Sáez, F.; Castro, E. Conversion of Olive Tree Biomass into Fermentable Sugars by Dilute Acid Pretreatment and Enzymatic Saccharification. Bioresour. Technol. 2008, 99, 1869-1876. [CrossRef] 
49. Barakat, A.; de Vries, H.; Rouau, X. Dry Fractionation Process as an Important Step in Current and Future Lignocellulose Biorefineries: A Review. Bioresour. Technol. 2013, 134, 362-373. [CrossRef] [PubMed]

50. Brandenburg, J.; Blomqvist, J.; Pickova, J.; Bonturi, N.; Sandgren, M.; Passoth, V. Lipid Production from Hemicellulose with Lipomyces Starkeyi in a PH Regulated Fed-Batch Cultivation. Yeast 2016, 33, 451-462. [CrossRef]

51. AOAC International. Official Methods of Analysis, 16th ed.; Garrard Press: Gaithersburg, MA, USA, 1995.

52. Li, Q.; Du, W.; Liu, D. Perspectives of Microbial Oils for Biodiesel Production. Appl. Microbiol. Biotechnol. 2008, 80, 749-756. [CrossRef]

53. Li, Y.; Zhao, Z.; Bai, F. High-density cultivation of oleaginous yeast Rhodosporidium toruloides Y4 in fed-batch culture. Enzyme Microb. Technol. 2007, 41, 312-317. [CrossRef]

54. Hassan, M.; Blanc, P.J.; Louis-marie, G.; Pareilleux, A.; Goma, G. Influence of nitrogen and iron limitations on lipid production by Cryptococcus curvatus grown in batch and fed-batch culture. Process Biochem. 1996, 31, 355-361. [CrossRef]

55. Vishniac, H.S. Yeast Biodiversity in the Antarctic. In Biodiversity and Ecophysiology of Yeasts; Péter, G., Rosa, C., Eds.; The Yeast Handbook; Springer: Berlin/Heidelberg, Germany, 2006; pp. 419-440, ISBN 978-3-540-30985-7.

56. R Core Team. R: A Language and Environment for Statistical Computing; R Foundation for Statistical Computing: Vienna, Austria, 2020. Available online: https:/ / www.r-project.org/ (accessed on 13 November 2021).

57. Patel, A.; Arora, N.; Mehtani, J.; Pruthi, V.; Pruthi, P. Assessment of Fuel Properties on the Basis of Fatty Acid Profiles of Oleaginous Yeast for Potential Biodiesel Production. Renew. Sustain. Energy Rev. 2017, 77, 604-616. [CrossRef]

58. Akbar, E.; Yaakob, Z.; Kamarudin, S.; Ismail, M.; Salimon, J. Characteristic and Composition of Jatropha curcas Oil Seed from Malaysia and Its Potential as Biodiesel Feedstock Feedstock. Eur. J. Sci. Res. 2009, 29, 396-403.

59. Ramos, M.J.; Fernández, C.M.; Casas, A.; Rodríguez, L.; Pérez, A. Influence of Fatty Acid Composition of Raw Materials on Biodiesel Properties. Bioresour. Technol. 2009, 100, 261-268. [CrossRef]

60. Liu, J.; Huang, X.; Chen, R.; Yuan, M.; Liu, J. Efficient Bioconversion of High-Content Volatile Fatty Acids into Microbial Lipids by Cryptococcus curvatus ATCC 20509. Bioresour. Technol. 2017, 239, 394-401. [CrossRef]

61. Murugan, S.; Bharathipriyadharsini, M.; Singaram, J. A Study on the Potential of Oleaginous Yeast in Producing Lipid from Garbage. Int. J. Appl. Eng. Res. 2015, 10, 346-350.

62. Sitepu, I.R.; Sestric, R.; Ignatia, L.; Levin, D.; German, J.B.; Gillies, L.A.; Almada, L.A.G.; Boundy-Mills, K.L. Manipulation of culture conditions alters lipid content and fatty acid profiles of a wide variety of known and new oleaginous yeast species. Bioresour. Technol. 2013, 144, 360-369. [CrossRef]

63. Raimondi, S.; Rossi, M.; Leonardi, A.; Bianchi, M.; Rinaldi, T.; Amaretti, A. Getting lipids from glycerol: New perspectives on biotechnological exploitation of Candida freyschussii. Microb. Cell Fact. 2014, 13, 83. [CrossRef] [PubMed]

64. Bao, W.; Li, Z.; Wang, X.; Gao, R.; Zhou, X.; Cheng, S.; Men, Y.; Zheng, L. Approaches to improve the lipid synthesis of oleaginous yeast Yarrowia lipolytica: A review. Renew. Sustain. Energy Rev. 2021, 149, 111386. [CrossRef]

65. Ratledge, $\mathrm{C}$. The role of malic enzyme as the provider of NADPH in oleaginous microorganisms: A reappraisal and unsolved problems. Biotechnol. Lett. 2014, 36, 1557-1568. [CrossRef]

66. Abeln, F.; Chuck, C.J. The Role of Temperature, PH and Nutrition in Process Development of the Unique Oleaginous Yeast Metschnikowia pulcherrima. J. Chem. Technol. Biotechnol. 2020, 95, 1163-1172. [CrossRef]

67. Nakagawa, Y.; Sakumoto, N.; Kaneko, Y.; Harashima, S. Mga2p Is a Putative Sensor for Low Temperature and Oxygen to Induce OLE1 Transcription in Saccharomyces cerevisiae. Biochem. Biophys. Res. Commun. 2002, 291, 707-713. [CrossRef]

68. Tezaki, S.; Iwama, R.; Kobayashi, S.; Shiwa, Y.; Yoshikawa, H.; Ohta, A.; Horiuchi, H.; Fukuda, R. $\Delta 12-$ Fatty Acid Desaturase Is Involved in Growth at Low Temperature in Yeast Yarrowia lipolytica. Biochem. Biophys. Res. Commun. 2017, 488, 165-170. [CrossRef]

69. Parsons, S.; Abeln, F.; McManus, M.C.; Chuck, C.J. Techno-Economic Analysis (TEA) of Microbial Oil Production from Waste Resources as Part of a Biorefinery Concept: Assessment at Multiple Scales under Uncertainty. J. Chem. Technol. Biotechnol. 2019, 94, 701-711. [CrossRef]

70. OECD-FAO Agricultural Outlook 2017-2026 Special Focus: Southeast Asia; OECD/FAO: Rome, Italy, 2017.

71. Parsons, S.; Raikova, S.; Chuck, C.J. The Viability and Desirability of Replacing Palm Oil. Nat. Sustain. 2020, 3, 412-418. [CrossRef]

72. Wicke, B.; Sikkema, R.; Dornburg, V.; Faaij, A. Exploring Land Use Changes and the Role of Palm Oil Production in Indonesia and Malaysia. Land Use Policy 2011, 28, 193-206. [CrossRef]

73. Fayle, T.M.; Turner, E.C.; Snaddon, J.L.; Chey, V.K.; Chung, A.Y.C.; Eggleton, P.; Foster, W.A. Oil Palm Expansion into Rain Forest Greatly Reduces Ant Biodiversity in Canopy, Epiphytes and Leaf-Litter. Basic Appl. Ecol. 2010, 11, 337-345. [CrossRef]

74. Danielsen, F.; Beukema, H.; Burgess, N.D.; Parish, F.; Brühl, C.A.; Donald, P.F.; Murdiyarso, D.; Phalan, B.; Reijnders, L.; Struebig, M.; et al. Biofuel Plantations on Forested Lands: Double Jeopardy for Biodiversity and Climate. Conserv. Biol. 2009, 23, 348-358. [CrossRef]

75. Germer, J.; Sauerborn, J. Estimation of the Impact of Oil Palm Plantation Establishment on Greenhouse Gas Balance. Environ Dev. Sustain. 2008, 10, 697-716. [CrossRef]

76. Bessou, C.; Chase, L.D.C.; Henson, I.E.; Abdul-Manan, A.F.N.; Milà i Canals, L.; Agus, F.; Sharma, M.; Chin, M. Pilot Application of PalmGHG, the Roundtable on Sustainable Palm Oil Greenhouse Gas Calculator for Oil Palm Products. J. Clean. Prod. 2014, 73, 136-145. [CrossRef] 
77. Angerbauer, C.; Siebenhofer, M.; Mittelbach, M.; Guebitz, G.M. Conversion of Sewage Sludge into Lipids by Lipomyces Starkeyi for Biodiesel Production. Bioresour. Technol. 2008, 99, 3051-3056. [CrossRef]

78. Zhu, L.Y.; Zong, M.H.; Wu, H. Efficient Lipid Production with Trichosporonfermentans and Its Use for Biodiesel Preparation. Bioresour. Technol. 2008, 99, 7881-7885. [CrossRef]

79. Vaishnav, A. Microbial Polymers: Applications and Ecological Perspectives; Springer Nature: Basingstoke, UK, 2021.

80. Rossi, M.; Buzzini, P.; Cordisco, L.; Amaretti, A.; Sala, M.; Raimondi, S.; Ponzoni, C.; Pagnoni, U.M.; Matteuzzi, D. Growth, lipid accumulation, and fatty acid composition in obligate psychrophilic, facultative psychrophilic, and mesophilic yeasts. FEMS Microbiol. Ecol. 2009, 69, 363-372. [CrossRef]

81. Chebbi, H.; Leiva-Candia, D.; Carmona-Cabello, M.; Jaouani, A.; Dorado, M.P. Biodiesel Production from Microbial Oil Provided by Oleaginous Yeasts from Olive Oil Mill Wastewater Growing on Industrial Glycerol. Ind. Crop. Prod. 2019, 139, 111535. [CrossRef]

82. Patel, A.; Arora, N.; Sartaj, K.; Pruthi, V.; Pruthi, P.A. Sustainable Biodiesel Production from Oleaginous Yeasts Utilizing Hydrolysates of Various Non-Edible Lignocellulosic Biomasses. Renew. Sustain. Energy Rev. 2016, 62, 836-855. [CrossRef]

83. Rizwanul Fattah, I.M.; Masjuki, H.H.; Kalam, M.A.; Hazrat, M.A.; Masum, B.M.; Imtenan, S.; Ashraful, A.M. Effect of Antioxidants on Oxidation Stability of Biodiesel Derived from Vegetable and Animal Based Feedstocks. Renew. Sustain. Energy Rev. 2014, 30, 356-370. [CrossRef]

84. Castellini, M.; Ubertini, S.; Barletta, D.; Baffo, I.; Buzzini, P.; Barbanera, M. Techno-Economic Analysis of Biodiesel Production from Microbial Oil Using Cardoon Stalks as Carbon Source. Energies 2021, 14, 1473. [CrossRef]

85. Barbanera, M.; Castellini, M.; Tasselli, G.; Turchetti, B.; Cotana, F.; Buzzini, P. Prediction of the Environmental Impacts of Yeast Biodiesel Production from Cardoon Stalks at Industrial Scale. Fuel 2021, 283, 118967. [CrossRef] 